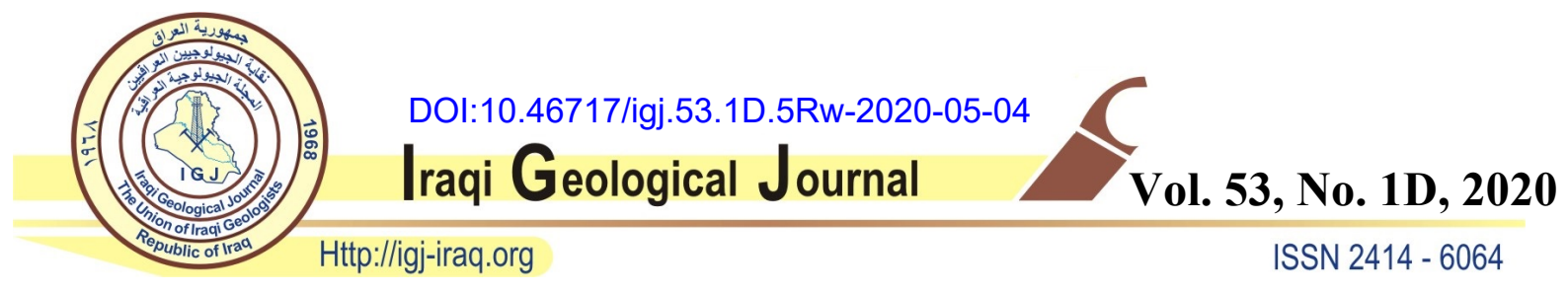

\title{
BIOSTRATIGRAPHY OF KHASIB FORMATION BY USING PLANKTONIC FORAMINIFERA AT SELECTED WELLS IN RUMILA OIL FIELD, SOUTHERN IRAQ
}

\author{
${ }^{1}$ Ruaa A. Al-Ali, ${ }^{1}$ Maher M. Mahdi' ${ }^{*}$ and ${ }^{1}$ Abbas H. Mohammed \\ ${ }^{1}$ Department of Geology, College of Science, University of Basrah \\ *Email: maher_mandeel@yahoo.com \\ Received: 23 January 2020; accepted: 18 February 2020
}

\begin{abstract}
Khasib Formation is one of the important formations in Iraq due to the wide spread and varying in thicknesses. In some oilfields like West Qurna, Khasib Formation represents a production reservoir. In this study, the selected fossils at this formation are studied precisely and ignored some species. In Rumaila Oilfield, eight oil wells were taken and fifty-five samples from planktonic foraminifera were collected, analyzed and identified. Twelve species belong to seven genera were chosen and diagnosed accurately, these are Marginotruncana scheegansi, Marginotruncana renzi, Clavihedbergella simplex, Whiteinella archeocretacea, Praeglobotruncana algeriana, Globotruncana imbricate, Globotruncana sigali, Heterohelix Russi, Heterohelix globulosa, Planoheterohelix globulosa, Heterohelix navarroensis, Heterohelix moreman. Marginotruncana scheegansi Assemblages Zone was suggested to the studied section. It corresponds with the regional zone of sigal (1977). The results of the present study showed that the formation age is Turonian-Coniacian, and there is no evidence of the Campanian age of Khasib Formation as mentioned in the previous studies.

Keywords: Khasib Formation; Rumaila oilfield; planktonic Foraminifera; Turonian; Coniacian; Iraq

\section{INTRODUCTION}

Khasib Formation is located within L. Turonian-E. Campanian sequence. The formation represents a few studies because it does not contain hydrocarbons, most of the studies focus on oil-formations like Mishrif and Zubair. The purpose of this study is to extract fossils from Khasib Formation by picking methods, while the other studied identified the fossils by thin sections, the latest studies conducted for the region by Darmoian (1975). The previous studies of the formation are related to
\end{abstract}


petroleum fields such as: (Al-Khayat and Razoyan, 1979; Al-Hamdani, 1986; Aqrawi, 1996; AlFatlawi, 2000; Al-Shaoosh, 2002; Al-Ani, 2004; Al Shujairi, 2017). Khasib Formation has extensive spreading in the middle and south of Iraq. The lower boundary with Mishrif Formation is disconformable, whereas in contrast to the top it is conformable with Tanuma Formation in southern Iraq with the first appearance of shale beds (Jassim and buday, 2006). The corresponding formation to the Khasib Formation in north Iraq was the lower part of Kometan Formation, while Al-Ghadeer Formation in Kuwait and Aroma limestone in Saudi Arabia (Al Shujairi, 2017). The aim of the study is to determine the age of the formation accurately, after extract the index fossils that belong to planktonic foraminifera.

\section{LOCATION OF THE STUDY AREA}

The Rumaila oilfield considers a huge oilfield that placed in the south of Iraq, the first drilling started in the middle of fifties with cooperation between Basrah Petroleum Company, and Iraq Petroleum Company. Seventeen billion barrels have been expected to the field production, therefore, Rumaila oilfield could be the 9th biggest oilfield in the world (Alsharan and Narin 1997, Handhal and Mahdi, 2016). The field situated about thirty-two km from Kuwaiti border and about fifty $\mathrm{km}$ west of the city of Basrah (Al-Ali et al., 2019). Rumaila Oilfield is divided into two parts North Rumaila and South Rumaila which are located within Mesopotamian zone, between the Abu Jir Zone to the southwest and the Makhul Zone to the northeast. The area described by the presence of several of subsurface anticlines with different forms, but these structures do not have terraces at the surface (Karim, 1989), (Almutury and Al-Asadi, 2008). The longitudinal axis of the Rumaila oilfield is about $80 \mathrm{~km}$, while the width is about $20 \mathrm{~km}$ (Al-Ali et al, 2019). Southern Oil Company is principle for production in Basrah city. Eight wells were selected for study based on their distribution in the field and on the availability of possible information that would benefit the study, as well as the availability of rock samples (Fig.1) and (Table 1).

\section{STRATIGRAPHIC SETTING}

Khasib Formation (Late Turonian- Early Campanian) was first described by Rabanit, (1952) in (Bellen et al., 1959), where the type section of the formation is well $\mathrm{Zb}-3$, located within the Mesopotamian region, which described by Owen and Nasr (1958). They mentioned that the lithology of Khasib is comprises double lithology, about $20 \mathrm{~m}$ of the formation consists of grey shale at the bottom, while the other part about $30 \mathrm{~m}$ comprises of grey argillaceous limestone (Bellen et al., 1959). 
Table 1. The coordinate of the studied wells with their depth and sample numbers

\begin{tabular}{|c|c|c|c|c|c|c|}
\hline Well No. & Well Name & X & Y & MD & TVDss & No. sample \\
\hline 1 & $\mathrm{R}-522$ & $30^{\circ} 33^{\prime} 21.51^{\prime \prime} \mathrm{N}$ & $47^{\circ} 18^{\prime} 55.96^{\prime \prime} \mathrm{E}$ & 2185.94 & 2169.23 & 6 \\
\hline 2 & $\mathrm{R}-530$ & $30^{\circ} 37^{\prime} 1.44^{\prime \prime} \mathrm{N}$ & $47^{\circ} 18^{\prime} 3.75^{\prime \prime} \mathrm{E}$ & 2178.93 & 2168.23 & 7 \\
\hline 3 & $\mathrm{R}-537$ & $30^{\circ} 28^{\prime} 33.47^{\prime \prime} \mathrm{N}$ & $47^{\circ} 18^{\prime} 56.18^{\prime \prime} \mathrm{E}$ & 2251.75 & 2203.56 & 6 \\
\hline 4 & $\mathrm{R}-659$ & $30^{\circ} 39^{\prime} 11.24^{\prime \prime} \mathrm{N}$ & $4^{\circ} 23^{\prime} 7.52^{\prime \prime} \mathrm{E}$ & 2289.75 & 2255.40 & 9 \\
\hline 5 & $\mathrm{Ru}-380$ & $30^{\circ} 18^{\prime} 8.10^{\prime \prime} \mathrm{N}$ & $47^{\circ} 21^{\prime} 59.19^{\prime \prime} \mathrm{E}$ & 2199.88 & 2147.87 & 7 \\
\hline 6 & $\mathrm{Ru}-410$ & $30^{\circ} 25^{\prime} 7.87^{\prime \prime} \mathrm{N}$ & $47^{\circ} 19^{\prime} 57.23^{\prime \prime} \mathrm{E}$ & 2238.98 & 2201.00 & 8 \\
\hline 7 & $\mathrm{Ru}-426$ & $30^{\circ} 14^{\prime} 23.29^{\prime \prime} \mathrm{N}$ & $47^{\circ} 22^{\prime} 27.68^{\prime \prime} \mathrm{E}$ & 2290.13 & 2120.39 & 7 \\
\hline 8 & $\mathrm{Ru}-451$ & $30^{\circ} 9^{\prime} 11.76^{\prime \prime} \mathrm{N}$ & $4^{\circ} 26^{\prime} 4.52^{\prime \prime} \mathrm{E}$ & 2229.74 & 2162.68 & 6 \\
\hline
\end{tabular}

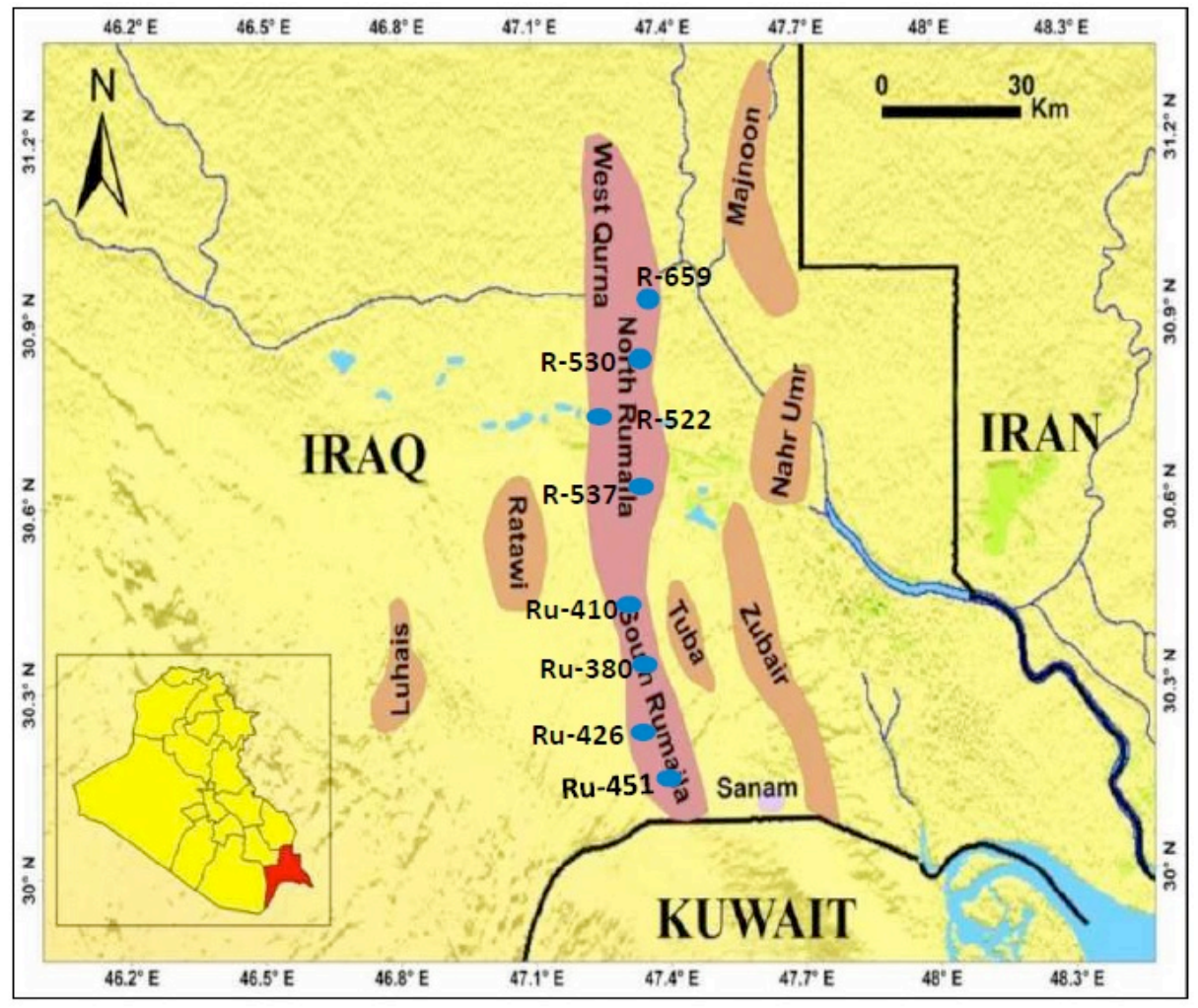

Fig. 1. Location map of the study area with selected wells (Jaffer, 2018)

Fossils are comparatively uncommon in the type section, the oligosteginal fauna and the dwarfed character of the fossils indicate the Khasib Formation was deposited in a restricted basin. Open marine Globotruncana assemblages are also present (Jassim and buday, 2006). 
Khasib Formation is the lower part of Late Turonian-Danian Megasequence AP9 which is split into two second-order sequence by Sharland et al., (2001). Mishrif Formation represents the unconformable regional surface with Khasib Formation resulting from the uplift erosion of Early Turonian. The top border is the conformable surface with the upper Cretaceous Tanuma Formation. From the shallow marine limestone to deep shelf of layering between limestone and shales of Khasib and Tanuma formations, there is a long period of depositional takeoff during the early Turonian.

Fatlawi (2000) through her study on the fossils in the Khasib Formation was attributed to the Upper Turonian, and was considered the first formation of the secondary sedimentary cycle (Turonian-Lower Campanian), which includes the Khasib, Tanuma and Saadi formations which are affected by single, high-repetitive post-hydrostatic movements at regular intervals, resulting in a change in the distribution and irregularity of the movement. This secondary cycle returns to the main cycle (Cenomanian-Lower Campanian) (Buday, 1980) and (Al Shujairi, 2017).

\section{METHODOLOGY}

Rock cutting samples were taken from the studied sections every $10 \mathrm{~m}$ in case of rock homogeneity, but in case of change in the rock lithology, the samples are taken for each $5 \mathrm{~m}, 56$ samples are the total samples from South and North Rumaila Oilfield. Due to the lack of Khasib Formation to the production of the oil at this field, the formation was not studied in detail and were not taken core samples only cutting samples. 100 gm from cutting samples were taken and then added the distilled water $400 \mathrm{ml}$ and then placed on the hot plate with the addition of the 5 gm sodium hydroxide for dispersion, then wash the sample and sieved by 63 micron sieve after drying of the sample. Subsequently, the fossils are packing by brush (000) under the normal microscope and then moved to the slide container for saving the fossils.

\section{SYSTEMATIC DESCRIPTION}

The systemic study is depended on Loeblich and Tappan's classification (1964) and Debenay (2012). The study fossils were picked from cutting samples which followed to Khasib Formation in Rumaila Oilfield for the selected wells, these are: RU-426, RU-380, RU-410, RU-451, R-537, R-659, R-522 and R-530. (R: N. Rumaila and RU: S. Rumaila).

Order Foraminifera d'Orbigny, 1826

Suborder Globigerinina Delage \& Hérouard, 1896

Superfamily Globotruncanoidea Brotzen, 1942 
Family Marginotruncanidae Pessagno, 1967

Subfamily Marginotruncaninae Pessagno, 1967

Genus Marginotruncana Hofker, 1956

Genus Marginotruncana scheegansi (Sigal)

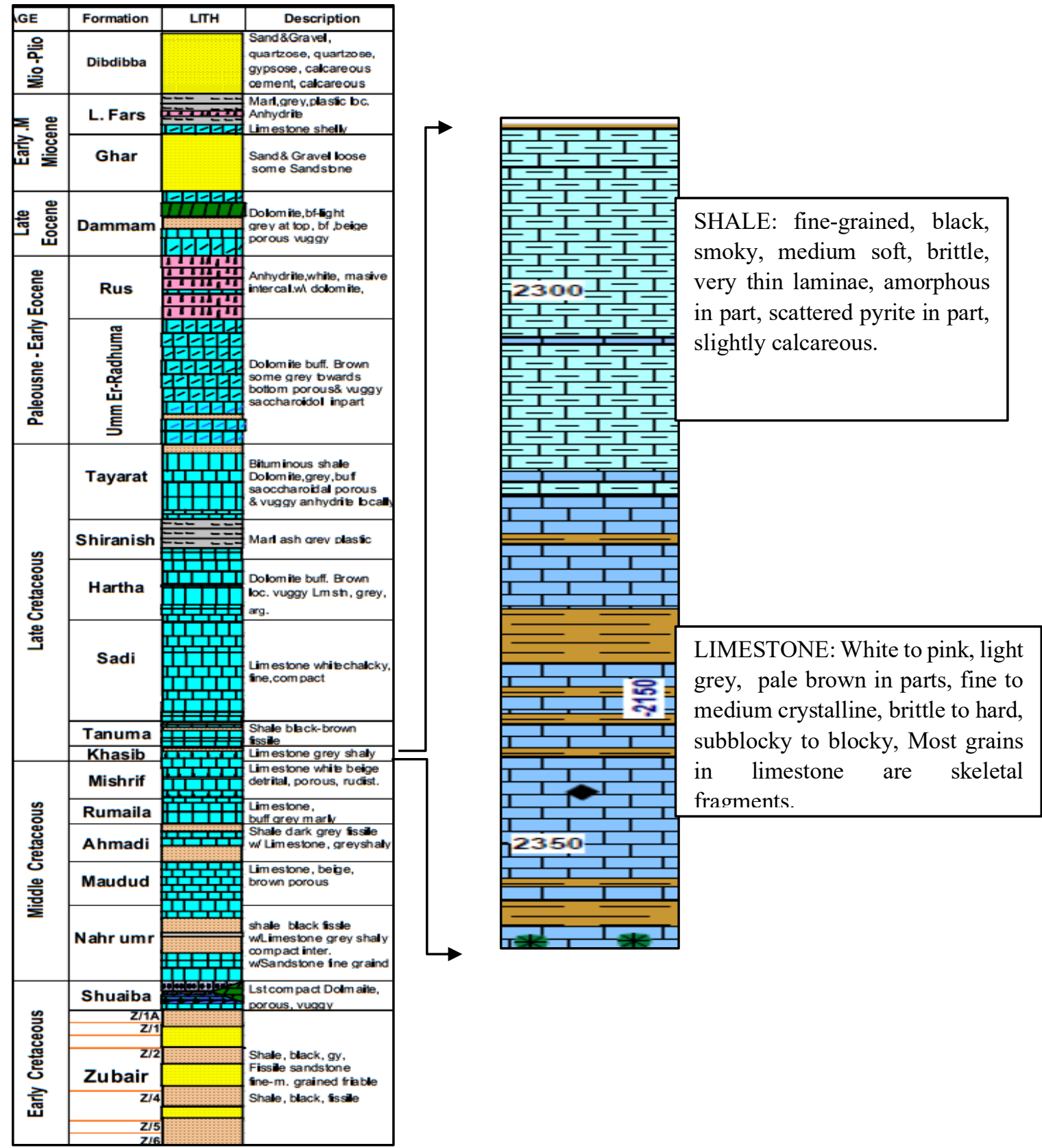

Fig. 2. Stratigraphic column to the typical section for Khasib Formation (RU-451) 
Description: Hyaline calcareous test wall, perforate, test small is trochospiral coiling, biconvex to planoconvex shape of chamber discoidal, number chamber between seven to nine, umbilicus area wide and shallow, aperture interiomarginal, suture line moderately depressed and be clear Plate 1 (A).

Geological Range: Turonian-Santonian

Genus Marginotruncana renzi (Gandolfi, 1942)

Description: Hyaline test low trochospiral, biconvex; slightly lobate at equatorial; two spread out keels convert to single keel on the last chamber. Chambers arched-shaped, 5 chambers in last whorl. On coiled side sutures bent to forward. On non-coiled side the sutures are seem as U-shape, Aperture is interiomarginal, Plate 1 (B).

Geological Range: Turonian- Santonian

Genus Clavihedbergella Loeblich,\& Tappan (1988).

Genus Clavihedbergella simplex (Morrow, 1934)

Description: Hyaline calcareous test wall, Test moderately to low trochoid; chambers completely globular, the second last chamber becoming somewhat elongate and the last chamber strongly elongate and calmly rounded at the end; chambers four in the final whorl, Plate 1 (C).

Geological Range: Albian -Coniacian

\section{Genus Whiteinella Pessagno 1967}

\section{Genus Whiteinella archeocretacea Pessagno, 1967}

Description: Hyaline calcareous test wall, pores randomly scattered, trochospiral coiling, shape of chamber spherical, umbilicus area thin and small, Chambers are organized on coiled side, number chambers is four to five, suture line slightly to moderately, Plate 1(D).

Geological Range Cenomanian - Santonian

Superfamily Globotruncanoidea Brotzen, 1942

Family Globotruncanoidea Brotzen, 1942

Subfamily Globotruncanoidea Brotzen, 1942

\section{Genus Praeglobotruncana Bermudez 1952}

\section{Genus Praeglobotruncana algeriana (Caron, 1966)}

Description: Hyaline calcareous test wall, pores randomly scattered, trochospiral coiling, shape of chamber spherical, umbilicus area, thin and small, Chamber arrangement coiled on trochospire, number chambers is five, the peripheral keel is double, aperture is not quite visible, suture line suture line moderately depressed, Plate 1 (E).

Geological Range: Turonian - Coniacian 


\section{Genus Globotruncana imbricata (Mornod, 1950)}

Description: Hyaline calcareous test wall. Test small is strongly involute, shape of chamber globular to subglobular, number chamber between six to eight, umbilicus area thin and deep, sutures deep depressed and be clear, the chambers increase quite rapidly but regularly in size resulting in a more inflated in chambers, aperture as a low arch, rims of keel weakly, wall finely perforate, smooth, Plate 1 (F).

Geological Range: Cenomanian - E. Coniacian

\section{Genus Globotruncana sigali (Reichel, 1950)}

Description: Hyaline calcareous test wall, test moderately high trochospiral, pores randomly scattered, trochospiral coiling, shape of chamber discoidal, number of chambers between eight to ten, Umbilicus wide and deep, suture line moderately depressed, two keels forming a snaky outline, aperture is not quite visible, Plate 2 (A).

Geological Range: Turonian - Santonia

Suborder Globigerinina Delage \& Herouard, 1896

Superfamily Heterohelicoidea Cushman, 1927

Family Heterohelicidae Cushman, 1927

Subfamily Heterohelicinae Cushman, 1927

Genus Heterohelix Ehrenberg, 1843

\section{Genus Heterohelix Russi Ehrenberg, 1840}

Description: Hyaline calcareous test wall, pores randomly scattered. Small test, biserial arrangement, the shape of test is triangle, the number of chambers eight to ten, shape of chamber equal globular, suture line moderately depressed, aperture interiomarginal, Plate 2 (B).

Geological Range: Cenomanian - Santonian

\section{Genus Heterohelix globulosa (Ehrenberg, 1840)}

Description: Hyaline calcareous test wall, inflated chambers compressed parallel to the line of junction between the two series of chambers, the zigzag suture scattered between chambers, pores randomly scattered, chamber organized as double serial, the number of chambers is six to eight, shape of chamber ovate, aperture intramarginal, Plate 2 (C).

Geological Range: Cenomanian -Maastrichtian

\section{Genus Planoheterohelix globulosa (Ehrenberg, 1840)}

Description: Hyaline calcareous test wall, pores randomly scattered. Test is chamber arrangement biserial, and gradually increasing in size chambers, number of chambers is eight to ten, shape of 
chamber globular to sub globular increasing slowly in size, aperture is an interiomarginal, Sutures are depressed and straight to slightly crooked, Plate 2 (D).

Geological Range: Cenomanian_ Maastrichtian

\section{Genus Heterohelix navarroensis loeblich, 1966}

Description: Hyaline calcareous test wall, pores randomly scattered. Test small subtriangular in side view, chamber arrangement biserial, the number of chambers are eight to ten, the chambers coil are low and not much inflated, shape of chamber globular and sub globular, spiral sutures moderately scattered, the main pore represent a short arch at the interior margin of the last chamber, Plate 2 (E).

Geological Range: Late Cretaceous

\section{Genus Heterohelix moreman, Cushman, 1938}

Description: Test wall is porcelain, pores randomly scattered, chamber arrangement biserial, the number of chamber is ten to twelve, shape of chamber subglobular to slightly reniform, suture line moderately depressed, aperture a high arched at the internal margin of the last chamber, Plate 2 (F).

Geological Range: Late Albian-Early Santonian

\section{BIOZONATION}

The results of the identified fossils at the selected wells are approximate, therefore they collected data in one figure (Fig. 3), the assemblage zone is a suitable zone for Khasib Formation because of existence three or more fossil taxa that, taken together, distinguishes it in biostratigraphic character from adjacent strata, such as Marginotruncana scheegansi, Marginotruncana renzi and Whiteinella archeocretacea. Therefore Marginotruncana scheegansi Assemblages Zone represents the recommended biozone for Khasib Formation, and this biozone corresponds partially with regional biozone of Sigal (1977), While the suggested age of Khasib Formation is Turonian - Coniacian, due to including the overlapping parts of the range zones of two specified taxa. The first appearance of Marginotruncana scheegansi represents the beginning of deposition of Khasib Formation at the Turonian age, as well as other fossils like Marginotruncana renzi and Globotruncana sigali, represent the end of the deposition of formation with last appearance of Praeglobotruncana algeriana in addition to Clavihedbergella simplex, with ending of Coniacian. This zone is closing to many regional studies that depending on index fossils for each period which illustrated in Figure (4). The paleontological studies were focused on Marginotruncana scheegansi species which indicated on Coniacian age with 
sometimes Globotruncana sigali, at north Iraq, Hammoudi (1995), emphasis the Marginotruncana Sigali and Dicarinella primitive are indicated to Coniacian age, but they not recorded at present study. Most neighbor countries do not depend on planktonic foraminifera, but rather on benthonic foraminifera (Nazzazata Taxon zone).

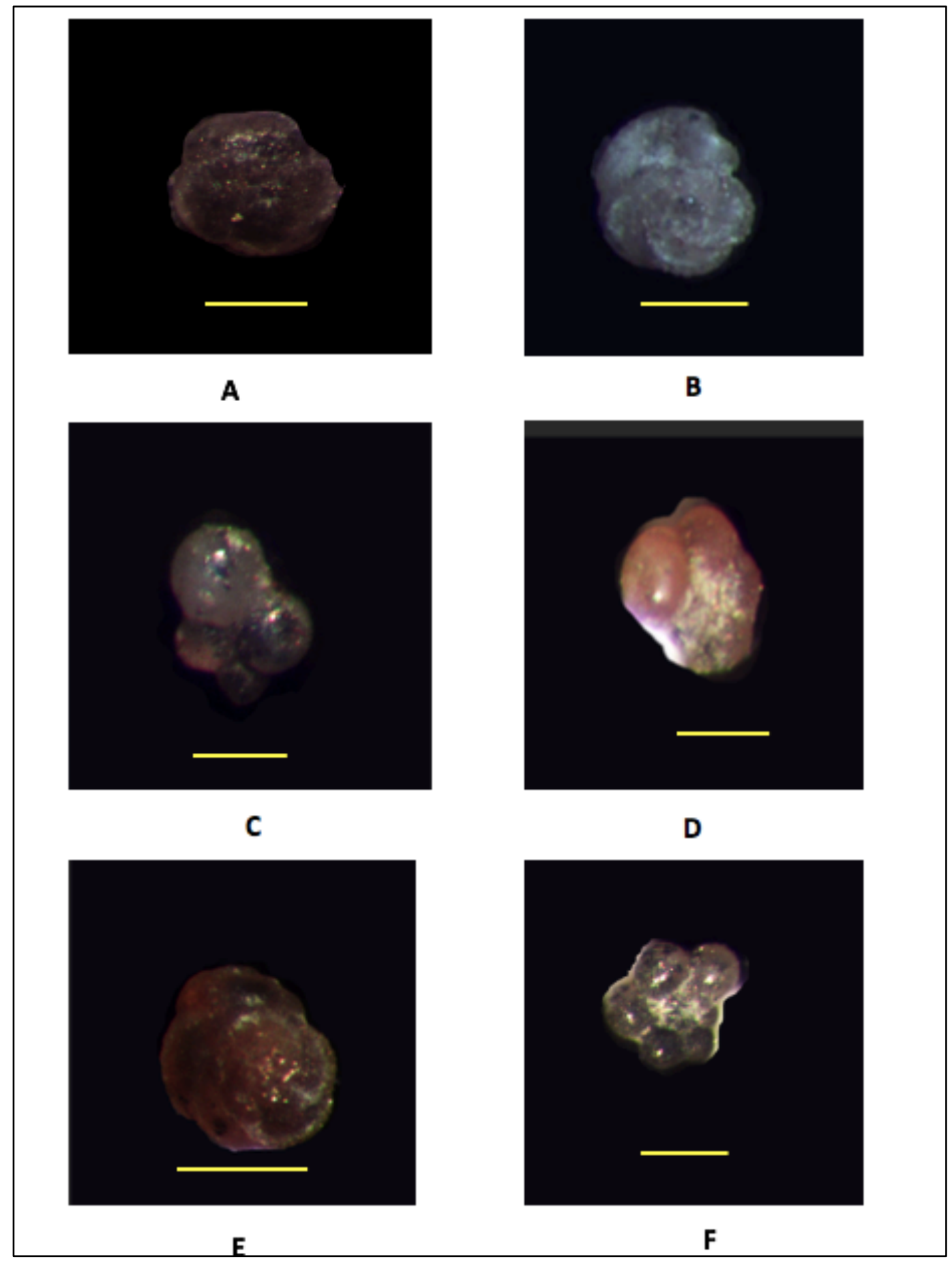

Plate 1. Planktonic foraminiferal fossils from the Khasib Formation, scale bar $=0.5 \mathrm{~mm}$ 


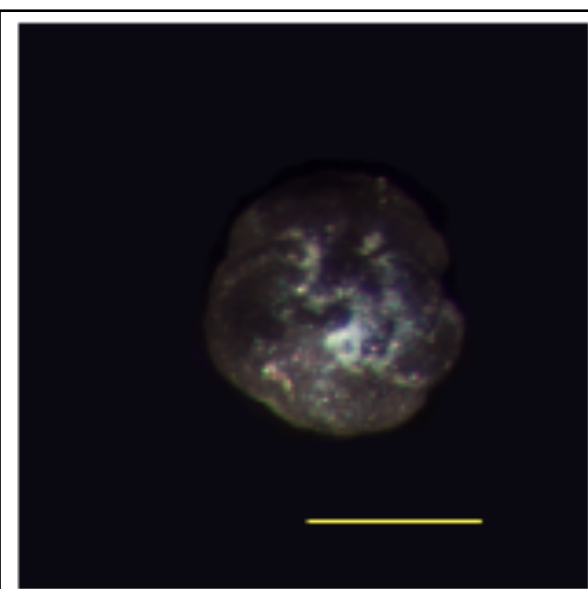

A

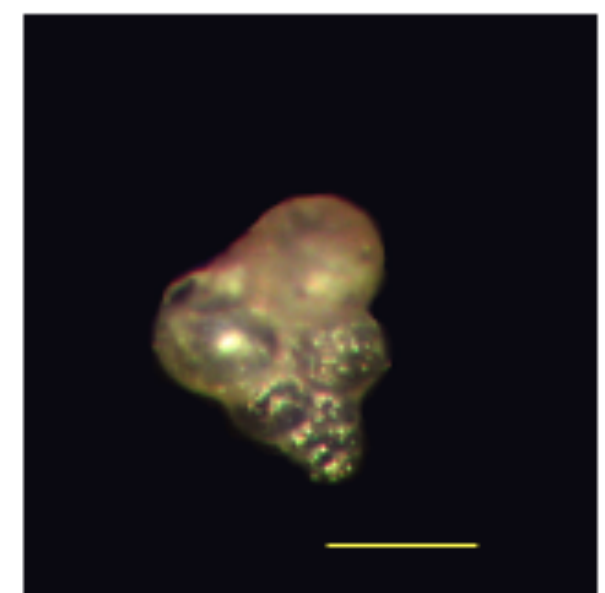

C

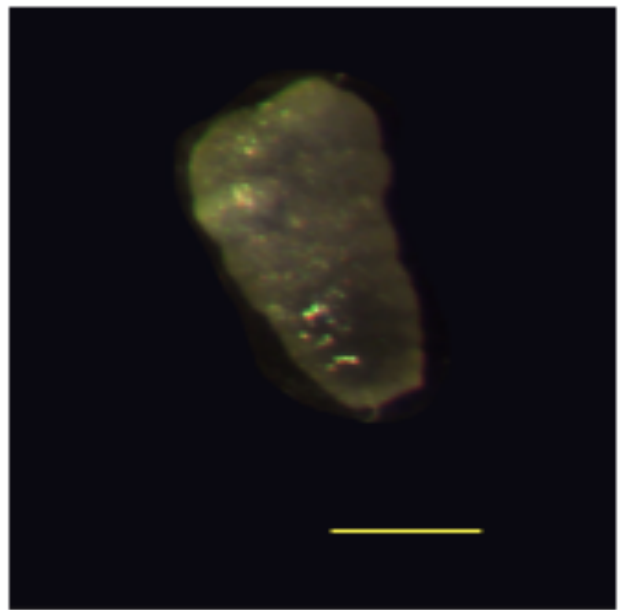

$\mathbf{E}$

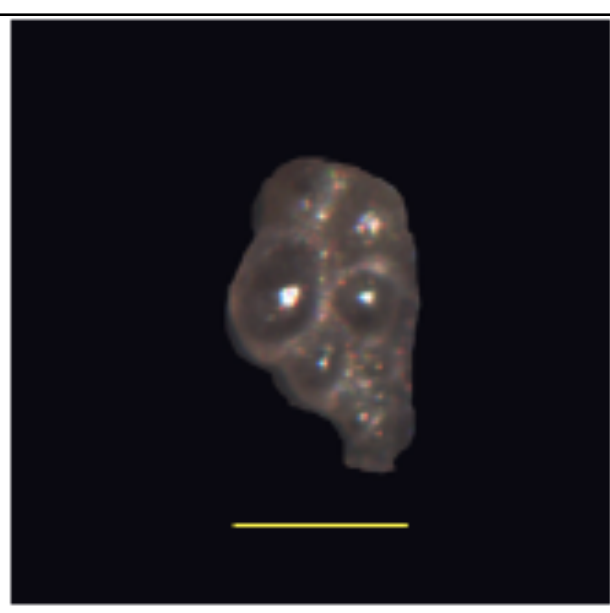

B

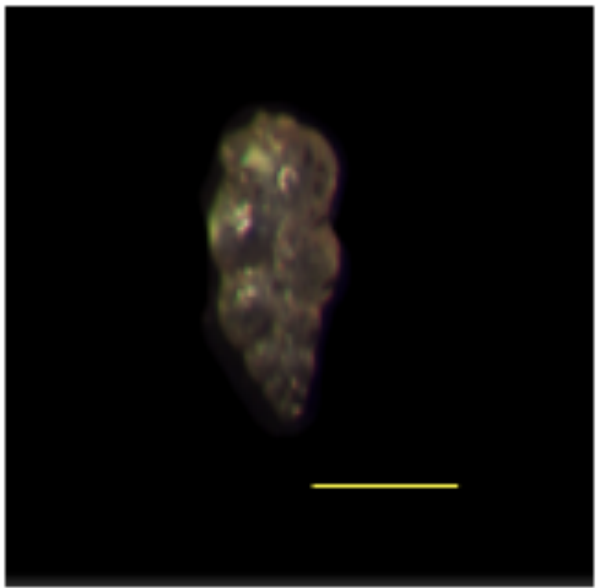

D

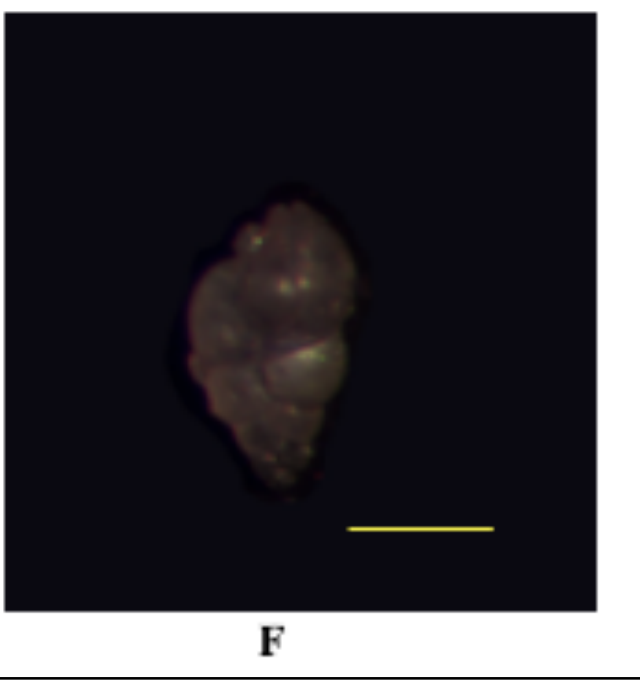

Plate 2. Planktonic foraminiferal fossils from the Khasib Formation, scale bar $=0.5 \mathrm{~mm}$ 


\section{DISCUSSION}

The current study aims to determine the age of Khasib Formation precisely, therefore after the collecting of fossils and classified them to determine the age for each of the picked species, they indicated that Khasib Formation is deposited at Turonian - Coniacian age. The stratigraphic position with sedimentary column for studied formation point to that the Khasib Formation was deposited at the Early Turonian age and could not be older than this age, there is important evidence for this age, the most significant of which is the presence of the following fossils: Marginotruncana scheegansi, Marginotruncana renzi and Globotruncana sigali, but these species could continue to appearance into Santonian age, while there are some of species ended at the contact of Khasib and Tanuma formations with Coniacian age, such as Globotruncana sigali, Praeglobotruncana algeriana, Globotruncana imbricata. The results of present study did not determine the continuation of the Khasib Formation until to the age of Companion that were identified by previous studies such as (Owen and Nasr, 1958, Bellen et al., 1959, Chatton and Hart, 1961) etc.

\section{CONCLUSION}

12 species belong to 7 genera were chosen and classified precisely from planktonic foraminifera followed to Khasib Formation, these are: Marginotruncana scheegansi, M. renzi, Clavihedbergella simplex, Whiteinella archeocretacea, Praeglobotruncana algeriana, Globotruncana imbricate, G. sigali, Heterohelix Russi, H. globulosa, Planoheterohelix globulosa, H. navarroensis, $H$. moreman. While the Marginotruncana scheegansi Assemblages Zone is determined in Khasib Formation. It equivalent to partially regional zones of Sigal's (1977) and Bolli (1966). The age of Khasib Formation is Turonian - Coniacian. 


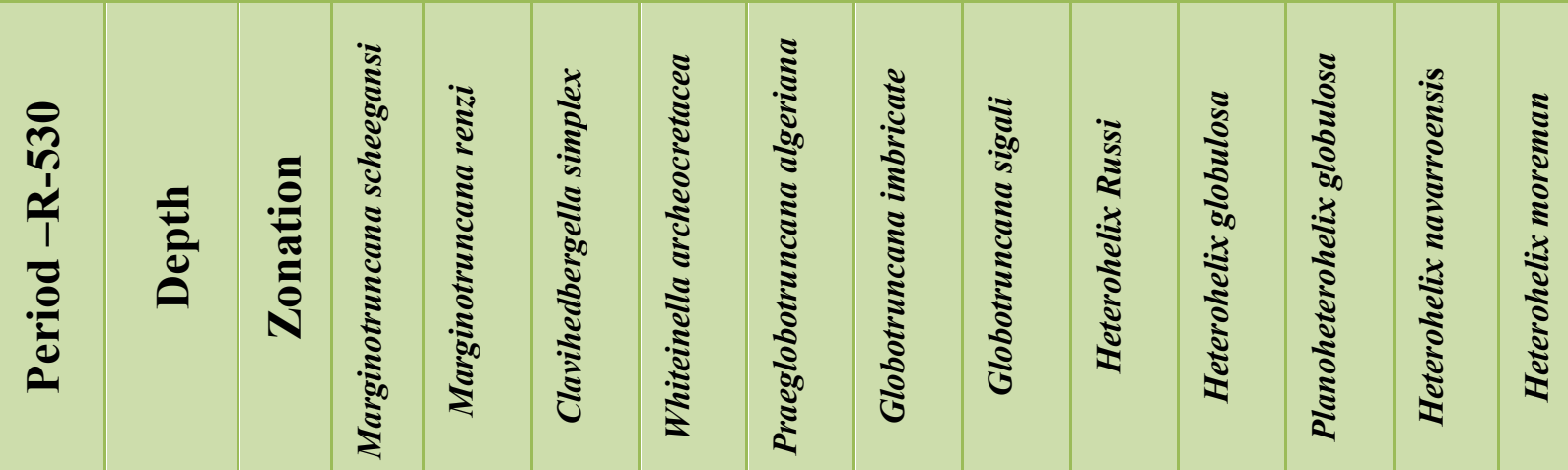

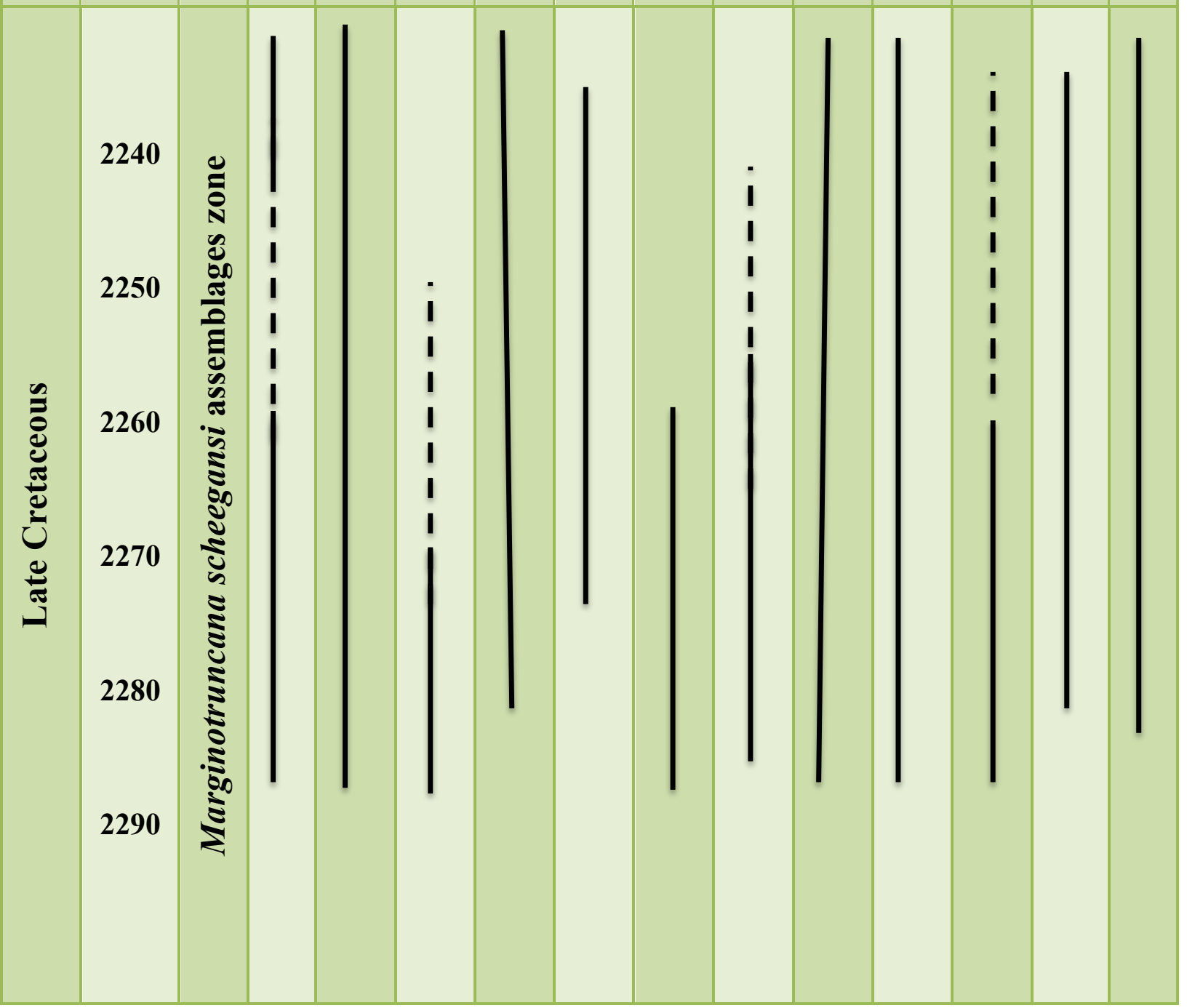

Fig. 3. Biostratigraphic ranges for identified taxa with suggested biozone, R- 530, North Rumila Oilfield 


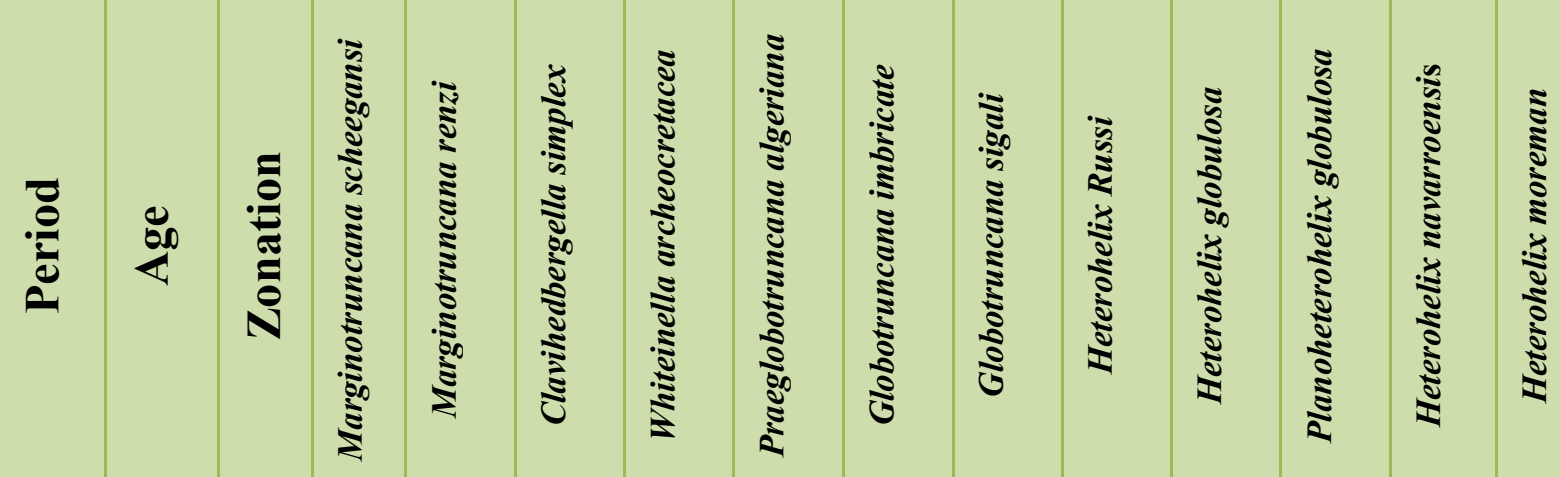

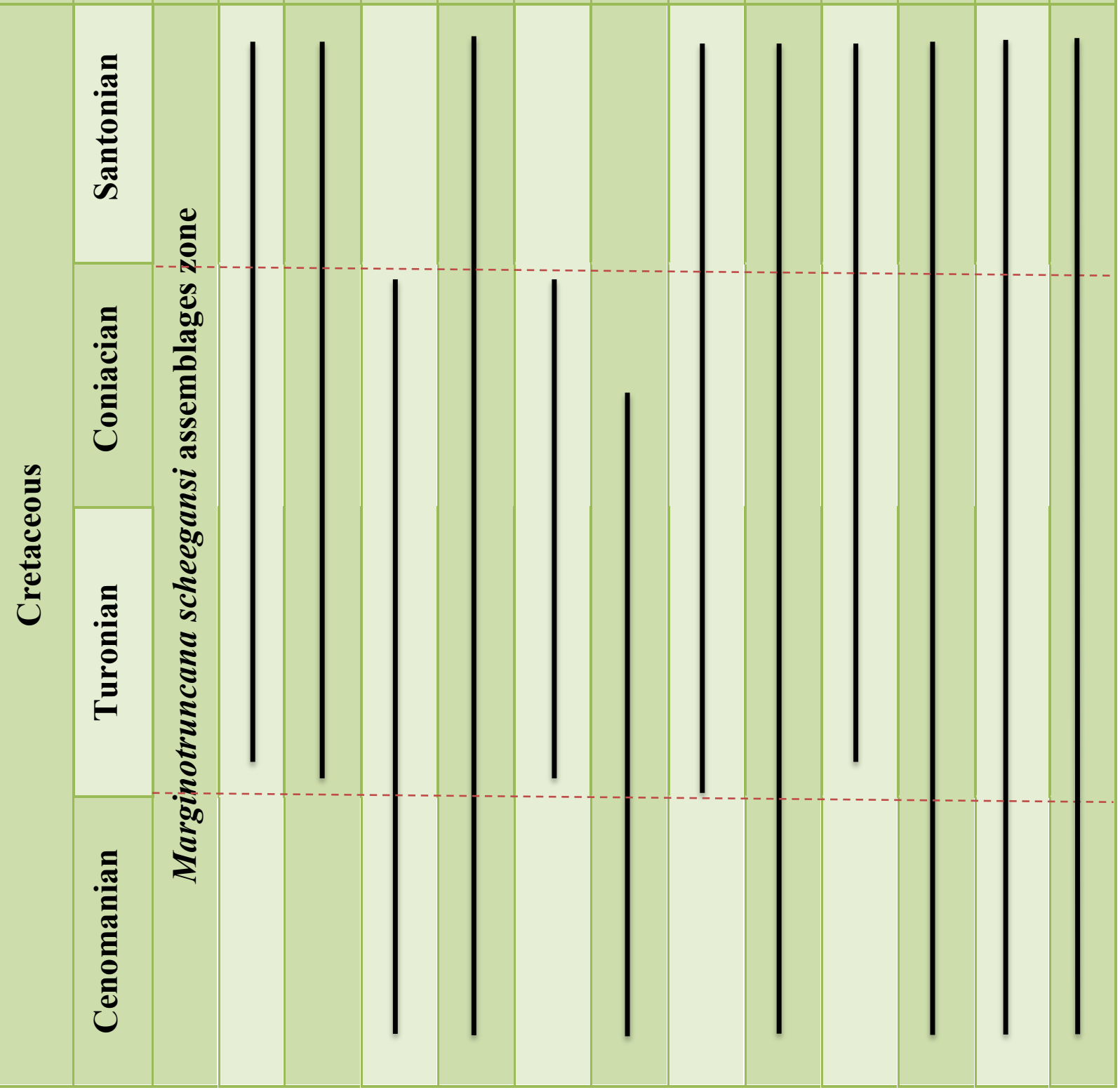

Fig. 4. The range of identified fossils to Khasib Formation and suggested biozone 


\begin{tabular}{|c|c|c|c|c|c|c|}
\hline \multicolumn{3}{|c|}{ Turonian } & \multicolumn{3}{|c|}{ Coniacian } & \multirow{2}{*}{ 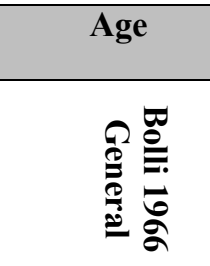 } \\
\hline \multicolumn{2}{|c|}{ 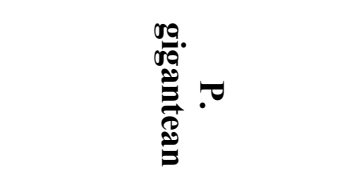 } & $\frac{\bar{\sigma}}{\frac{\sigma}{2}}=$ & \multicolumn{3}{|c|}{ 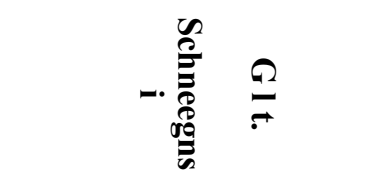 } & \\
\hline \multicolumn{2}{|c|}{ 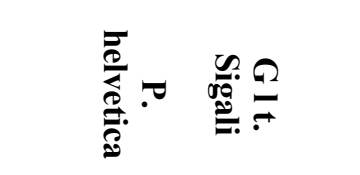 } & 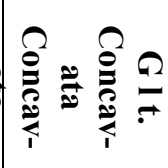 & $\stackrel{2}{\approx}$ & $\frac{2}{2}$ & 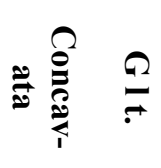 & 司 \\
\hline 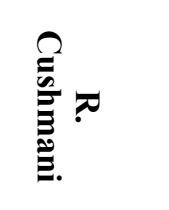 & 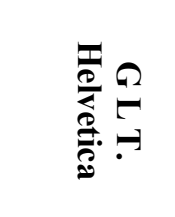 & 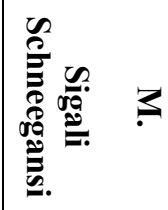 & \multicolumn{3}{|c|}{ 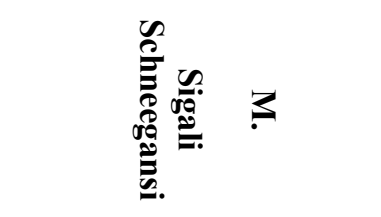 } & - \\
\hline 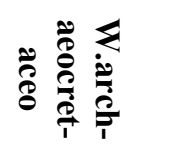 & $\begin{array}{l}\frac{\pi}{2} \\
\frac{\pi}{2} \\
\frac{a}{2}\end{array}$ & 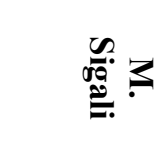 & \multicolumn{3}{|r|}{ 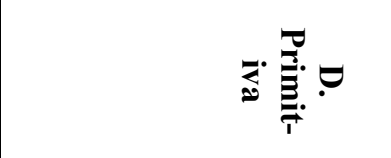 } & 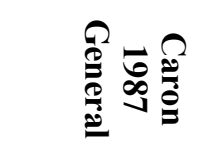 \\
\hline \multicolumn{2}{|l|}{ 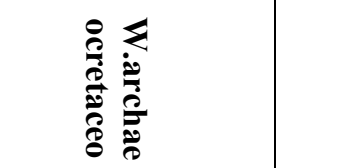 } & 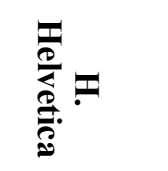 & \multicolumn{3}{|r|}{ 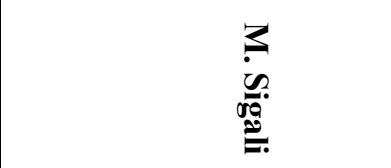 } & 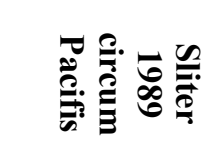 \\
\hline \multicolumn{3}{|c|}{ 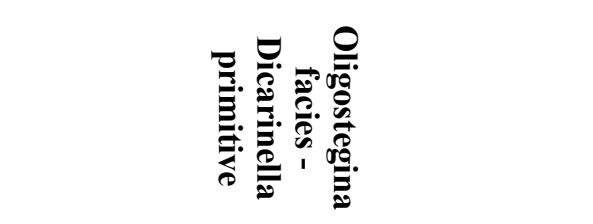 } & \multicolumn{3}{|c|}{ 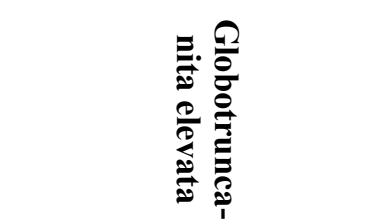 } & 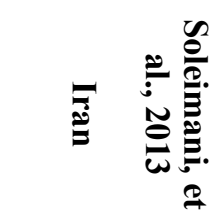 \\
\hline & & & 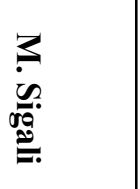 & & •: & قِ \\
\hline \multicolumn{6}{|c|}{ 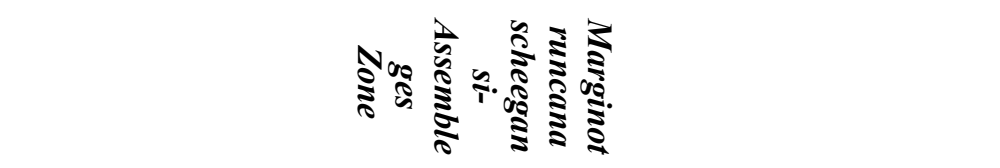 } & 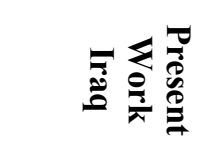 \\
\hline
\end{tabular}

Fig. 5. Correlation of biostratigraphic zones of present study with other regional studies (modified of Hammoudi, 1995)

\section{REFERENCES}

Al-Ali, M., Mahdi, M. M., and Alali, R., 2019. Microfacies and depositional environment of Mishrif Formation, North Rumaila oil field, southern Iraq, Iraqi Geological Journal, 52(2): 91- 104.

Al-Ani, A. L, 2004. Depositional Environment and Reservoir Characterization of the Khasib Formation in East Baghdad Oilfield, unpub.MSc thesis, University of Baghdad, 123 P.

Al-Fatlawi, I. R, 2000. The Fine Facies and the Age of the Khasib Formation, Unpub. MS thesis, College of Science, University of Baghdad, $134 \mathrm{P}$. 
Al-Siddiki, A., 1978. Subsurface Geology of Southern Iraq, Tenth Arab petroleum congress Tripoli Libya.

Al-Shaoosh, M. A, 2002. Sequence Stratigraphy and Depositional Systems of (Late Turonian - Early Campanian) Cycles, Khasib, Tanuma and Sa'di Formations, in west Qurna Oil Field Southern Iraq Southern Iraq, Un pub.MS thesis, College of Science, University of Basrah $134 \mathrm{P}$.

AL-Khayat, A. and Razoyan, A. M., 1979. The Geology of Sadi, Tanuma, Khasib and Mishrif Formations in Halfya Field: Unpublished report, INOC, Basrah,23p.

Al-Hamdani, A. M., 1986. Stratigraphy and Geochemistry of Khasib, Tanuma and Sadi Formations, Unpublished Ph. D. thesis, Baghdad University, $328 \mathrm{P}$.

Al-Mutury, W.G., Al-Asadi, M. M., 2008. Tectonostratigraphic history of mesopotamian passive margin during mesozoic and cenozoic, South Iraq. J Kirkuk Univ-Sci Stud., 3(1):31-50.

Al-Sharhan, A. S, Narin, A. E. M., 1997. Sedimentary Basins and Petroleum Geology of the Middle East. Elsevier, the Netherlands, $843 \mathrm{P}$.

Al Shujairi, M. H, 2017. Stratification and Basin Analysis for the Khasib Formation of Selected Wells from Southern Iraq, College of Science University of Babylon.

Aqrawi, A. A. M., 1996. Carbonate-Siliciclastic sediments of the upper Cretaceous (Khasib, Tanuma and Sa'adi Formations) of the Mesopotamian basin. Marine and Petroleum Geology.

Barr, F. T., 1972. Cretaceous biostratigraphy and planktonic Foraminifera of Libya, Micropaleontology, 18(1): 1-46.

Bellen, R. C., Van, Dunnington, H. V., Wetzel, R., and Morton, D. M., 1959. Lexique Stratigraphique, International. Asia, Iraq, Internat. Geol.Cong. Comm. Stratig., 3(10a): 333 P.

Bolli, H. M., 1966. Zonation of Cretaceous to Pliocene marine sediments based on planktonic Foraminifera, Bull. Inform. Ass. Venezolana Geol Min., 9: 3-32.

Buday, T., 1980. The Regional Geology of Iraq. Vol.1: Stratigraphy and Palaeogeography, Publications of GEOSURV, Baghdad. 445 P.

Caron, M., 1987, General Cretaceous Planktonic Foraminifera, In: Bolli, H. M., J. R. Saunders and K. Perch- Nielaem, (eds.) Planktonic Stratigraphy, Cambrigde Univ. Press, PP. 17-86, Figs. 37.

Chatton, M., and Hart, E., 1961. Review of the Cenomanian to Maastrichtian stratigraphy in Iraq. Manuscript report, No. $2 / 14$ 1, INOC Library, Baghdad.

Darmoian, S. A., 1975. Planktonic foraminifera from the Upper Cretaceous of Southern Iraq. Biostratigraphy and systematic of the Heterohelicidae. Micropal., 21(2): 185-214.

Debenay, J. P., 2012. A Guide to 1,000 Foraminifera from Southwestern Pacific, Publications Scientifiques du Muséum, Muséum national d'Histoire naturelle, Paris, 386 P.

Ditmar, V., and Iraq-Soviet, 1972. Geological Condition and Hydrocarbon Prospect of the Republic of the Iraq, Vol. II, South Iraq Maniscript report, INOC. Library, Baghdad.

Hammoudi, R. A., 1995. Stratigraphy of The Turonian- Early Companian Depositional Subcycle From Selection Wells In Iraq, unpub.Ph.D thesis, University of Mosul, 270P.

Handhal, A. M., and Mahdi, M. M., 2016. Basin modeling analysis and organic maturation for selected wells from different oil fields, Southern Iraq, Model. Earth Syst. Environ., 2(189): 1-14.

Jaffar, H. M., 2018. Structural Geology of Rumaila Oilfield in Southern Iraq from Well Logs and Seismic Data, Unpub. Msc. Thesis, University of Basrah, $104 \mathrm{P}$.

Jassim, S. Z., and Buday, T., 2006. Late Thronian-Danian Megasequence AP9 in Jassim, S. Z. Goff, J. C. Geology of Iraq. Published by Dolin, Prague and Moravian Museum, Berno.

Loeblich, A. R., and Tappan, H., 1964. Treatise on Invertebrate Paleontology, Sarcodina, chiefly Thecamoeblans and Foraminiferida .The University of Kansas Press and.Geol. Soc.Ame .Part C,Protista 2,V.P.2900.

Owen, R. M., and Nasr, S. N., 1958. The stratigraphy of the Kuwait-Basrah area. In: Weeks, G.L. (es). Habitat of oil a symposium. Amer. Assoc. Pet. Geol. Tulsa. Petroleum Geologists Bulletin.

Saddoni, F. N., and Aqrawi, A. A. M., 2000. Cretaceous Sequence Stratigraphy and Petroleum Potential of the Mesopotamian Basin, Iraq. In: AL- Sharhan, A.S. and Scotty, R. W. (eds.), Middle East Models of Jurassic/Cretaceous Carbonate Systems. SEPM Spec. Publ.

Sharland, P. R., 2001. Sharland, P. R., Archer, P. R, Casey, D. M., Davies, R. B., Hall, S. H, Heward, A. P., Horbury, A.D., and Simmons, M. D. S, 2001. Arabian plate sequence stratigraphy, an intedrated approach, Geo Arabia , speciel publcaition, Manama, Bahrain, $340 \mathrm{P}$.

Sigal, J., 1977. Essai de zonation du Cretace Mediterraneen a 1' aide des Foraminiferes Planctoniques : geologic Mediterraneen, 99-108, in French.

Sliter, W., 1989. Biostratigraphic zonation for Cretaceous planktonic Foraminiferes Examined in Thin Section, Jour. Foram. Resseach, 19(1): 1-19.

Soleimani, B., Bahadori, A., Meng, F., 2013. Microbiostratigraphy, microfacies and sequence stratigraphy of upper cretaceous and paleogene sediments, Hendijan oilfield, Northwest of Persian Gulf, Iran, Natural Science, 5(11): 1165-1182. 